\title{
A NOVEL ANALYSIS OF THE RISK OF FRESH PRODUCE IMPORTS
}

\author{
E.R. FRAMPTON ${ }^{1}$ and K. NALDER ${ }^{2}$
${ }^{1}$ Critique Limited, 587 Springston-Rolleston Road, $R$ D 8, Christchurch 7678, New Zealand \\ ${ }^{2}$ New Zealand Fresh Produce Importers Association, PO Box 24322, Manners \\ Street, Wellington, New Zealand
}

Corresponding author: framptonr@critiquelimited.co.nz.

\begin{abstract}
The types of organisms detected entering New Zealand on fresh produce (i.e. organisms intercepted during inspection at the border and/or intercepted post-border) were compared with the types of organisms that have recently been reported as established in New Zealand (i.e. organisms with population(s) detected and/or reported for the first time in New Zealand). Of the 420 new-to-New Zealand records from 1990$2007,65.7 \%$ and $33.8 \%$ were pathogens and invertebrates, respectively. In contrast, over $96 \%$ of 19,127 border interception identification records and 499 post-border interception records from 2003-2006 were invertebrates. Of the 104 new-to-New Zealand insect and mite species, 12 were intercepted on fresh produce. The mismatches between the types of organisms intercepted and new-to-New Zealand records revealed in this novel analysis indicate that commercially imported fresh produce does not constitute a major pathway for establishment of exotic pests in New Zealand. Present phytosanitary measures (preborder, border and post-border) appear appropriate to managing the risk. Keywords: entry, establishment, interception, new-to-New Zealand, fresh produce, import pathway, phytosanitary measures.
\end{abstract}

\section{INTRODUCTION}

Trade is an essential part of New Zealand's primary production-based economy. With increasing trade, there are numerous pathways for the entry and establishment of new organisms. Obviously these risks need to be managed with the development and implementation of appropriate sanitary/phytosanitary measures. Commercially imported fresh produce for consumption, defined by MAF Biosecurity New Zealand as 'fresh fruit and vegetables' (MAF 2008), is but one import pathway that requires management. Fresh produce importers believe that the present phytosanitary measures (as defined in FAO (2007)) for commercial fresh produce adequately mitigate the risk of regulated pests (as defined in FAO (2007)) establishing in New Zealand via the commercial fresh produce pathway.

The novel analysis described here is an attempt to test this view by a comparison of the types of organisms detected entering New Zealand on fresh fruit and vegetables (i.e. those organisms intercepted during inspection at the border and/or intercepted post-border) and the types of organisms that have recently been reported as established in New Zealand (i.e. those non-vertebrate organisms for which population(s) were detected for the first time in New Zealand in association with plants and/or the environment, including those that are believed to be part of New Zealand's previously undescribed native flora and fauna). In the future, similar analyses of other import pathways may assist in providing an indication of the relative risk of establishment of new organisms via these pathways. 


\section{MATERIALS AND METHODS}

Ministry of Agriculture and Forestry (MAF) maintains detailed fresh produce border interception and post-border interception records in the Specimen Tracking and Reporting System (STARS) Database. Similarly, new-to-New Zealand records (as defined above) are maintained in the Plant Pest Information Network (PPIN) Database. Extracts from the PPIN and STARS Databases were obtained in August 2007 from the Investigation and Diagnostic Centre (IDC), MAF Biosecurity New Zealand, for the purposes of this analysis. Specifically, details of all 420 new-to-New Zealand records from 1990 to August 2007 inclusive were extracted from the PPIN Database and provided as an Excel file. Extracted records did not include those that at that time were not for public information (usually records that were pending validation). Similarly, details of any fresh produce border interception and post-border interception records from 1 January 2003 to 31 December 2006 were extracted from the STARS Database and provided as two Excel files, one containing 19,127 border interception identification records and the other containing 499 post-border interception identification records.

With reference to the taxonomic groups assigned to these PPIN and STARS records, a summary of each data set was compiled. Subsequently, these summaries were directly compared. Initial analysis involved combining taxonomic groups broadly, e.g. bacteria, Chromista, fungi, phytoplasmas, viroids and viruses were grouped as 'pathogens', earthworms, insects, leeches, millipedes, mites, molluscs, nematodes, spiders and the likes were grouped as 'invertebrates'. Given the predominance of invertebrate interceptions recorded in association with fresh produce imports, further analysis focused on invertebrates. It involved searching the border and post-border interception records for those invertebrate species that had recently been reported as established in New Zealand. In addition, a comparison between species intercepted at the border and post-border is presented.

\section{New-to-New Zealand records}

\section{RESULTS AND DISCUSSION}

The taxonomic groups applying to PPIN Database records at the time the records were extracted were: alga, bacterium, Chromista, earthworm, fungus, insect, leech, millipede, mite, nematode, phytoplasma, plant, snail, spider, viroid and virus. Of the 420 new-toNew Zealand records during the period 1990-August 2007, Table 1 shows the number of new records in each taxonomic group.

If the taxonomic groups are combined into invertebrates, pathogens and algae or plants, the percentages of the new-to-New Zealand records falling into these broader groupings are $33.8 \%, 65.7 \%$ and $0.5 \%$, respectively. Very similar results had been obtained from earlier analysis of all 311 new-to-New Zealand records for the period 1990 to April 2004 with $34.1 \%, 65.6 \%$ and $0.3 \%$ falling into the broader groupings of invertebrates, pathogens and plants, respectively (Frampton 2004). It must not be assumed, however, that all of these new-to-New Zealand records comprise exotic organisms that have recently arrived in New Zealand. A portion of the records relate to organisms that are believed to be part of New Zealand's previously undescribed or unrecognised flora and fauna (e.g. Ycaploca sp. nr evansi and Anacharis zealandica).

\section{Fresh produce interception records}

Table 2 provides summaries of the border and post-border interception data sets. Compared to Table 1, there are a number of additional taxonomic groups represented in the border interception data set. These include centipede, crustacean, flatworm, mollusc (as well as slug and snail, which belong to the phylum Mollusca), pseudoscorpion and slater.

If the taxonomic groups are combined into invertebrates, pathogens and others, the percentages of both border interception and post-border interception records falling into the invertebrate and pathogen groupings are $>96 \%$ and $3.2 \%$, respectively. In contrast to the new-to-New Zealand data, there is a predominance of invertebrate records in these two interception data sets. This predominance may be accentuated through the 
TABLE 1: Number of new-to-New Zealand records in each taxonomic group contained in the PPIN Database extract.

\begin{tabular}{lrc}
\hline Taxonomic group & Number & Percentage \\
\hline Pathogens & & \\
Bacterium & 8 & 1.90 \\
Chromista & 15 & 3.57 \\
Fungus & 220 & 52.38 \\
Phytoplasma & 2 & 0.48 \\
Viroid & 4 & 0.95 \\
Virus & 27 & 6.43 \\
\hline
\end{tabular}

Invertebrates

\begin{tabular}{lrr} 
Earthworm & 2 & 0.48 \\
Insect & 97 & 23.09 \\
Leech & 1 & 0.24 \\
Millipede & 0 & 0 \\
Mite & 16 & 3.81 \\
Nematode & 21 & 5.00 \\
Slug & 0 & 0 \\
Snail & 2 & 0.48 \\
Spider & 3 & 0.71 \\
\hline Alga & 1 & 0.24 \\
Plant & 1 & 0.24 \\
\hline Total ${ }^{1}$ & 420 & 100.00 \\
\hline
\end{tabular}

${ }^{1}$ Includes new descriptions of New Zealand's biota.

inspection process, which involves visual examination of a defined sample of any fresh produce consignment. Clearly visual examination will not detect microscopic organisms contaminating the fresh produce, although obvious symptoms of fungal infections (e.g. lesions or external hyphal growth) in the sample will be identified. Countering this, however, is the need for exporters to ensure fresh produce is of the highest quality otherwise consignments will not even reach the desired markets let alone be suitable for sale and subsequent consumption.

Although the percentages of both border interception and post-border interception records falling into the broad invertebrate and pathogen groupings are very similar, the proportions of individual invertebrate taxonomic groups differ considerably. Notably, spiders make up just $2.13 \%$ of the border interceptions but $26.85 \%$ of post-border interceptions. In contrast, mites make up $24.94 \%$ of the border interceptions but only $3.81 \%$ of post-border interceptions (Table 2). This may be due to the observational skills of trained MAF staff undertaking fresh produce inspections as opposed to the bias (for larger, more mobile organisms) of the public in reporting post-border finds. 
TABLE 2: Identification records in each taxonomic group contained in the STARS Database extracts of border and post-border interceptions from fresh produce during the period January 2003-December 2006.

\begin{tabular}{|c|c|c|c|c|}
\hline \multirow{2}{*}{$\begin{array}{l}\text { Taxonomic group } \\
\text { (as recorded) }\end{array}$} & \multicolumn{2}{|c|}{ Border interceptions } & \multicolumn{2}{|c|}{ Post-border interceptions } \\
\hline & Number & Percentage & Number & Percentage \\
\hline \multicolumn{5}{|l|}{ Pathogens } \\
\hline Bacterium & 7 & 0.04 & 2 & 0.40 \\
\hline Chromista & 8 & 0.04 & & \\
\hline Fungus & 601 & 3.14 & 14 & 2.81 \\
\hline Phytoplasma & 0 & 0 & & \\
\hline Viroid & 0 & 0 & & \\
\hline Virus & 0 & 0 & & \\
\hline \multicolumn{5}{|l|}{ Invertebrates } \\
\hline Centipede & 34 & 0.18 & 1 & 0.20 \\
\hline Crustacean & 1 & 0.01 & & \\
\hline Earthworm & 164 & 0.86 & & \\
\hline Flatworm & 3 & 0.02 & & \\
\hline Insect & 10,798 & 56.45 & 322 & 64.53 \\
\hline Leech & 1 & 0.01 & & \\
\hline Millipede & 75 & 0.39 & & \\
\hline Mite & 4,771 & 24.94 & 19 & 3.81 \\
\hline Mollusc & 22 & 0.12 & & \\
\hline Nematode & 1,882 & 9.84 & 1 & 0.20 \\
\hline Pseudoscorpion & 10 & 0.05 & 2 & 0.40 \\
\hline Slater & 26 & 0.14 & & \\
\hline Slug & 14 & 0.07 & 2 & 0.40 \\
\hline Snail & 189 & 0.99 & 1 & 0.20 \\
\hline Spider & 408 & 2.13 & 134 & 26.85 \\
\hline Worm & 10 & 0.05 & & \\
\hline \multicolumn{5}{|l|}{ Others } \\
\hline Alga & 2 & 0.01 & & \\
\hline Plant & 97 & 0.51 & 1 & 0.20 \\
\hline Vertebrate & 1 & 0.01 & & \\
\hline ID 'Not recorded' & 3 & 0.02 & & \\
\hline Total & 19,127 & 100.00 & 499 & 100.00 \\
\hline
\end{tabular}

\section{Further analysis}

Given the predominance of insect and mite interceptions recorded in association with fresh produce imports, further analysis involved direct comparison of the new-to-New Zealand insects and mites with interception records of those species of insects and mites. The results of this comparison are shown in Table 3.

From Table 1, the number of new-to-New Zealand insect and mite records totals 113. The 104 listed in Table 3 includes several species (e.g. Solenopsis invicta and Hyphantria cunea) for which there is more than one record/incursion. Notably, of the 104 insect and mite species that have recently been reported as established in New Zealand, 
12 species (10 insect species and 2 species of mite) or $11.5 \%$ have been intercepted on fresh produce during the 2003-2006 period. Collectively, these 12 species were identified on 169 occasions, which represents $0.9 \%$ of the total number of interception identification records from fresh produce imports. There are an additional 25 species $(24.0 \%)$ that have not been intercepted but other species in the same genus have.

Of the 10 insect species that have recently been reported as established in New Zealand and have been intercepted on fresh produce imports during the 4 years, 2003-2006 inclusive, four belong to the hymenopteran family, Formicidae (ants). The four species are Anoplolepis gracilipes (yellow crazy ant), Paratrechina longicornis (crazy ant), Solenopsis geminata and Solenopsis invicta (red imported fire ant). Of the other six species, one belongs to each of three hemipteran families, Aphididae, Diaspididae and Pseudococcidae, Isotenes miserana belongs to the lepidopteran family Tortricidae, Lachesilla pedicularia belongs to the psocopteran family Lachesillidae and Frankliniella intonsa to the thysanopteran family, Thripidae. All five mite species belong to the Order Prostigmata, while the three species of Tarsonemus belong to the family Tarsonemidae and the two species of Tydeus to the family Tydeidae.

As with Hyphantria cunea (fall webworm), Lymantria dispar (gypsy moth) and Teia anartoides (painted apple moth), all four of the ant species: Anoplolepis gracilipes and Paratrechina longicornis in April 2002 (MAF 2002); Solenopsis geminata; and S. invicta in March 2001, February 2004 (MAF Biosecurity New Zealand 2008) and June 2006 (MAF 2007), have been subject to post-border control/eradication efforts such that although monitoring continues, their current pest status in New Zealand would be officially defined as "Absent; pest eradicated" (FAO 1998). Pathways other than the commercial fresh produce pathway have also been implicated in the entry (MAF 2003a,b) and establishment (e.g. A. gracilipes from sawn timber imports (MAF 2003b)) of ants.

For completeness, the post-border and border interception records were examined more closely to determine whether those species intercepted post-border had also been detected/intercepted at the border. As shown in Table 4, overall 90 of the $174(51.7 \%)$ species intercepted post-border had also been intercepted at the border. Notably some insect orders are intercepted post-border more frequently than others, e.g. Lepidoptera, Hemiptera and Coleoptera. Furthermore, a few species can be seen to contribute disproportionately to the post-border interception records (e.g. Antichloris viridis (banana moth) and Neotoxoptera formosana (onion aphid)).

It must be noted that like any large data sets there are some limitations to the data used for this analysis. Practically, the data relate to evolving MAF operations including the adoption of different or additional phytosanitary measures for fresh produce imports, changing data recording systems as well as the availability of new diagnostic techniques. Thus the data used for the analysis described above covered time periods for which comparable identification records could be extracted from the relevant existing MAF databases. Consequently, it is highly unlikely that particular new-to-New Zealand records can be linked to certain imports. Notably, new-to-New Zealand records from the PPIN Database covered a long time period predating the interception and identification of organisms recorded in the STARS Database from 2003-2006. This perhaps raises issues about the value of the approach. Nevertheless, it is considered that in conjunction with other approaches to analysing the risk of new organisms establishing in New Zealand (e.g. Worner \& Gevrey 2006), the novel approach adopted here has the potential to guide additional risk assessment of related invasive species in prominent taxonomic groups and/or research into more effective management. 
TABLE 3: Listing of new-to-New Zealand species of insects and mites showing the number of occasions that those species and species within the same genus have been intercepted on fresh produce at the border or post-border from 2003-2006.

\begin{tabular}{|c|c|c|c|c|}
\hline \multirow{2}{*}{$\begin{array}{l}\text { Taxonomic } \\
\text { group (Order) }\end{array}$} & \multirow{2}{*}{$\begin{array}{l}\text { Scientific name of } \\
\text { new-to-NZ record }\end{array}$} & \multicolumn{2}{|c|}{$\begin{array}{l}\text { No. occasions } \\
\text { intercepted }\end{array}$} & \multirow{2}{*}{$\begin{array}{c}\text { Other species } \\
\text { in same genus } \\
\text { intercepted? }\end{array}$} \\
\hline & & Border & Post-border & \\
\hline Blattidae & Imblattella orchidae & 0 & 0 & No \\
\hline Coleoptera & Stricticomus tobias & 0 & 0 & No \\
\hline Coleoptera & Nathrius brevipennis & 0 & 0 & No \\
\hline Coleoptera & Peltoschema suturalis & 0 & 0 & No \\
\hline Coleoptera & Rodolia koebelei & 0 & 0 & No \\
\hline Coleoptera & Serangium maculigerium & 0 & 0 & No \\
\hline Coleoptera & Coccotrypes dactyliperda & 0 & 0 & No \\
\hline Coleoptera & Emplesis bifoveata & 0 & 0 & No \\
\hline Coleoptera & Hypurus bertrandi & 0 & 0 & No \\
\hline Coleoptera & Sitona lepidus & 0 & 0 & No \\
\hline Coleoptera & Xenocnema spinipes & 0 & 0 & No \\
\hline Coleoptera & Attagenus pellio & 0 & 0 & Yes \\
\hline Coleoptera & Aridius bifasciatus & 0 & 0 & Yes \\
\hline Coleoptera & Aphodius fimetarius & 0 & 0 & Yes \\
\hline Coleoptera & Phyllotocus macleayi & 0 & 0 & No \\
\hline Diptera & Contarinia sp. & 0 & 0 & No \\
\hline Diptera & Lestodiplosis sp. & 0 & 0 & No \\
\hline Diptera & Chamaemyia polystigma & 0 & 0 & No \\
\hline Diptera & Smittia sp. $(\operatorname{not} S$. verna $)$ & 0 & 0 & Yes \\
\hline Diptera & Cryptochaetum iceryae & 0 & 0 & No \\
\hline Diptera & Pygophora apicalis & 0 & 0 & No \\
\hline Diptera & Leia arsona & 0 & 0 & No \\
\hline Diptera & Sciophila ocreata & 0 & 0 & No \\
\hline Diptera & Sciophila parviareolata & 0 & 0 & No \\
\hline Diptera & Bradysia sp. nr brunnipes & 0 & 0 & Yes \\
\hline Diptera & Bradysia paupera & 0 & 0 & Yes \\
\hline Diptera & Boreoides tasmaniensis & 0 & 0 & No \\
\hline Diptera & Dioxyna sororcula & 0 & 0 & No \\
\hline Hemiptera & Orchamoplatus citri & 0 & 0 & No \\
\hline Hemiptera & Rhopalosiphum sp. & 0 & 0 & Yes \\
\hline Hemiptera & Euceraphis betulae & 0 & 0 & Yes \\
\hline Hemiptera & Nasonovia ribis-nigri & 1 & 0 & No \\
\hline Hemiptera & Aphis epilobii & 0 & 0 & Yes \\
\hline Hemiptera & Brachycaudus rumexicolens & 0 & 0 & Yes \\
\hline Hemiptera & Bathyllus albicinctus & 0 & 0 & No \\
\hline Hemiptera & Ceroplastes ceriferus & 0 & 0 & Yes \\
\hline Hemiptera & Pulvinaria hydrangeae & 0 & 0 & Yes \\
\hline
\end{tabular}




\begin{tabular}{|c|c|c|c|c|}
\hline \multirow{2}{*}{$\begin{array}{l}\text { Taxonomic } \\
\text { group (Order) }\end{array}$} & \multirow{2}{*}{$\begin{array}{l}\text { Scientific name of } \\
\text { new-to-NZ record }\end{array}$} & \multicolumn{2}{|c|}{$\begin{array}{l}\text { No. occasions } \\
\text { intercepted }\end{array}$} & \multirow{2}{*}{$\begin{array}{c}\text { Other species } \\
\text { in same genus } \\
\text { intercepted? }\end{array}$} \\
\hline & & Border & Post-border & \\
\hline Hemiptera & Chrysomphalus aonidum & 4 & 0 & Yes \\
\hline Hemiptera & Furchadaspis zamiae & 0 & 0 & No \\
\hline Hemiptera & Parlatoria desolator & 0 & 0 & Yes \\
\hline Hemiptera & Lepidosaphes pallida & 0 & 0 & Yes \\
\hline Hemiptera & Heterogaster urticae & 0 & 0 & No \\
\hline Hemiptera & Planococcus citri & 27 & 2 & Yes \\
\hline Hemiptera & Creiis liturata & 0 & 0 & No \\
\hline Hemiptera & Anoeconeossa communis & 0 & 0 & No \\
\hline Hemiptera & Megadrymus terraereginae & 0 & 0 & No \\
\hline Hemiptera & Bactericera cockerelli & 0 & 0 & No \\
\hline Hymenoptera & Camarothorax sp. & 0 & 0 & No \\
\hline Hymenoptera & Sycoscapter australis & 0 & 0 & No \\
\hline Hymenoptera & Encarsia inaron & 0 & 0 & Yes \\
\hline Hymenoptera & Euryglossina hypochroma & 0 & 0 & No \\
\hline Hymenoptera & Baeoanusia albifunicle & 0 & 0 & No \\
\hline Hymenoptera & Coccidoctonus psyllae & 0 & 0 & No \\
\hline Hymenoptera & Psyllaephagus gemitus & 0 & 0 & No \\
\hline Hymenoptera & Psyllaephagus sp. nov. & 0 & 0 & No \\
\hline Hymenoptera & Syrphophagus aphidivorus & 0 & 0 & No \\
\hline Hymenoptera & Cirrospilus vittatus & 0 & 0 & No \\
\hline Hymenoptera & Neotrichoporoides viridimaculatus & tus 0 & 0 & No \\
\hline Hymenoptera & Sympiesis sericeicornis & 0 & 0 & No \\
\hline Hymenoptera & Anacharis zealandica & 0 & 0 & No \\
\hline Hymenoptera & Cardiocondyla minutior & 0 & 0 & Yes \\
\hline Hymenoptera & Monomorium salomonis (group) ${ }^{1}$ & 0 & 0 & Yes \\
\hline Hymenoptera & Solenopsis invicta ${ }^{1}$ & 1 & 0 & Yes \\
\hline Hymenoptera & Paratrechina longicornis ${ }^{1}$ & 17 & 0 & Yes \\
\hline Hymenoptera & Pheidole proxima & 0 & 0 & Yes \\
\hline Hymenoptera & Anoplolepis gracilipes ${ }^{1}$ & 8 & 0 & No \\
\hline Hymenoptera & Monomorium sydneyense & 0 & 0 & Yes \\
\hline Hymenoptera & Solenopsis geminata ${ }^{1}$ & 8 & 0 & Yes \\
\hline Hymenoptera & Anthidium manicatum & 0 & 0 & No \\
\hline Hymenoptera & Neopolycystus insectifurax & 0 & 0 & No \\
\hline Hymenoptera & Ycaploca sp. nr evansi & 0 & 0 & No \\
\hline Hymenoptera & Radumeris tasmaniensis & 0 & 0 & No \\
\hline Hymenoptera & Nematus oligospilus & 0 & 0 & No \\
\hline Hymenoptera & Dolichovespula media ${ }^{1}$ & 0 & 0 & No \\
\hline Hymenoptera & Polistes olivaceus ${ }^{1}$ & 0 & 0 & No \\
\hline Isoptera & Porotermes adamsoni & 0 & 0 & No \\
\hline Lepidoptera & Hyphantria cunea $^{1}$ & 0 & 0 & No \\
\hline Lepidoptera & Coscinoptycha improbana & 0 & 0 & No \\
\hline Lepidoptera & Depressaria pastinacella & 0 & 0 & No \\
\hline Lepidoptera & Dialectica scalariella & 0 & 0 & No \\
\hline
\end{tabular}




\begin{tabular}{|c|c|c|c|c|}
\hline \multirow{2}{*}{$\begin{array}{l}\text { Taxonomic } \\
\text { group (Order) }\end{array}$} & \multirow{2}{*}{$\begin{array}{l}\text { Scientific name of } \\
\text { new-to-NZ record }\end{array}$} & \multicolumn{2}{|c|}{$\begin{array}{l}\text { No. occasions } \\
\text { intercepted }\end{array}$} & \multirow{2}{*}{$\begin{array}{c}\text { Other species } \\
\text { in same genus } \\
\text { intercepted? }\end{array}$} \\
\hline & & Border & Post-border & \\
\hline Lepidoptera & Teia anartoides ${ }^{1}$ & 0 & 0 & No \\
\hline Lepidoptera & Lymantria dispar ${ }^{1}$ & 0 & 0 & No \\
\hline Lepidoptera & Uraba lugens & 0 & 0 & No \\
\hline Lepidoptera & Holocola sp. cf. triangulana & 0 & 0 & No \\
\hline Lepidoptera & Isotenes miserana & 1 & 0 & No \\
\hline Lepidoptera & Artona martini & 0 & 0 & No \\
\hline Orthoptera & Pterapotrechus sp. & 0 & 0 & No \\
\hline Psocoptera & Lachesilla pedicularia & 2 & 0 & Yes \\
\hline Thysanoptera & Frankliniella intonsa & 1 & 0 & Yes \\
\hline Acariformes & Neomolgus sp. & 0 & 0 & No \\
\hline Acariformes & Neomolgus sp. nr lumarius & 0 & 0 & No \\
\hline Acariformes & Hemicheyletia scutellata & 0 & 0 & Yes \\
\hline Acariformes & Prosocheyla sp. nr oaklandia & 0 & 0 & Yes \\
\hline Acariformes & Cryptognathus cucurbita & 0 & 0 & No \\
\hline Acariformes & Armascirus sp. nr virginiensis & 0 & 0 & Yes \\
\hline Acariformes & Cecidophyopsis hendersoni & 0 & 0 & No \\
\hline Acariformes & Oziella yисcаe & 0 & 0 & No \\
\hline Acariformes & Tarsonemus waitei & 85 & 0 & Yes \\
\hline Acariformes & Tarsonemus sp. nr randsi & 0 & 0 & Yes \\
\hline Acariformes & Tarsonemus sp. nr bakeri & 14 & 0 & Yes \\
\hline Acariformes & Tydeus sp. nr lambi & 0 & 0 & Yes \\
\hline Acariformes & Tydeus reticulatus & 0 & 0 & Yes \\
\hline Parasitiformes & SPhorytocarpais fimetorum & 0 & 0 & No \\
\hline$\underline{\text { Parasitiformes }}$ & sHolaspulus tenuipes & 0 & 0 & No \\
\hline
\end{tabular}

${ }^{1}$ Species recorded as new-to-New Zealand and subsequently eradicated from New Zealand.

Specifically, in regard to the pest identification details, limitations to the data were more apparent in the STARS Database records. For example, in the post-border interception records (501 in total), there were two records for which no information on the identification was available (i.e. an empty cell). Furthermore, there were 117 records for which genus and species names were not or could not be recorded, of which $33 \mathrm{had}$ no 'Family' name recorded. Similarly, the border interception data set comprising 19,487 records in total contained 360 records for which no information on the identification was available. In addition, over 7000 records had no genus and species names noted (i.e. 'Indet. Indet.' or similar, or an empty cell) and where a genus name was recorded, some 5150 had no species name given (i.e. 'sp.'). This, in turn, makes it very difficult to determine accurately whether intercepted organisms are regulated or non-regulated, and therefore what risk they constitute. An earlier similar analysis showed a good portion of intercepted organisms to be non-regulated (Frampton 2004). Importantly, even if the condition or lifestage of an intercepted organism allows for identification, the dearth of taxonomic descriptions and/or appropriate diagnostic keys (morphological, molecular, etc.) makes identification of all intercepted organisms to the genus and species level impossible. That is not to say, that any potential risk cannot be managed. 
Although many of the interception records did not include identifications to the genus and species level, analysis of the broad taxonomic groups of intercepted organisms provides some insights into the risk presented by a particular pathway. If the pathway was contributing significantly to the establishment of new organisms in New Zealand, the types of organisms recently reported as established in New Zealand could be expected to match the types of organisms detected entering New Zealand (as indicated by interceptions). This analysis of the fresh produce pathway revealed a number of mismatches between the types of organisms intercepted and new-to-New Zealand records: (i) about two-thirds of the new-to-New Zealand records since 1990 were pathogens, yet very few pathogens have been intercepted on commercial fresh produce imports; and (ii) most interceptions on fresh produce were insects or mites, while just one-third (33.8\%) of the new-to-New Zealand records were invertebrates. Furthermore, of the 104 insect and mite species that have been detected in New Zealand since 1990, 12 (11.5\%) were intercepted on fresh produce in the 4-year period, 2003-2006 inclusive.

TABLE 4: A comparison of post-border interception records with border interception records from fresh produce contained in the STARS Database extract for the period January 2003-December 2006.

\begin{tabular}{|c|c|c|c|}
\hline $\begin{array}{l}\text { Taxonomic group } \\
\text { (as recorded) }\end{array}$ & $\begin{array}{c}\text { Number of post- } \\
\text { border records }\end{array}$ & $\begin{array}{l}\text { No. species recorded } \\
\text { post-border }^{1}\end{array}$ & $\begin{array}{l}\text { No. 'post-border' species } \\
\text { intercepted at the border }\end{array}$ \\
\hline Bacterium & 2 & 2 & 1 \\
\hline Fungus & 14 & 11 & 8 \\
\hline Centipede & 1 & 1 & 1 \\
\hline Insect: & 322 & 99 (excluding 55) & 56 \\
\hline Blattodea & 5 & 5 & 3 \\
\hline Coleoptera & 44 & 23 (excluding 5) & 9 \\
\hline Diptera & 22 & 11 (excluding 8) & 5 \\
\hline Ephemeroptera & 1 & 1 & 0 \\
\hline Hemiptera & $56^{2}$ & 15 (excluding 4) & 13 \\
\hline Hymenoptera & 27 & 15 (excluding 11) & 7 \\
\hline Lepidoptera & $154^{3}$ & 23 (excluding 23) & 17 \\
\hline Neuroptera & 2 & 1 & 1 \\
\hline Orthoptera & 6 & 4 (excluding 2) & 0 \\
\hline Thysanoptera & 5 & 1 (excluding 2) & 1 \\
\hline Mite & 19 & 11 (excluding 2) & 9 \\
\hline Nematode & 1 & 1 & 0 \\
\hline Pseudoscorpion & 2 & 2 & 0 \\
\hline Slug & 2 & 2 & 0 \\
\hline Snail & 1 & 1 & 0 \\
\hline Spider & 134 & 43 (excluding 59) & 15 \\
\hline Plant & 1 & 1 & 0 \\
\hline Total & 499 & 174 & 90 \\
\hline
\end{tabular}

${ }^{1}$ Excluding records, as noted, where the genus and species were not determined.

${ }^{2} 33=$ Neotoxoptera formosana, onion aphid, a non-regulated pest.

${ }^{3} 54=$ Antichloris viridis, banana moth, a regulated pest. 
In summary, a comparison of the types of organisms detected entering New Zealand on fresh produce with those that have recently been reported as established in New Zealand appears to provide some insights into the risks presented by this particular pathway. The results of the analysis described above tend to support the view that the present phytosanitary measures for commercial fresh produce imports adequately mitigate the risk of new organisms establishing in New Zealand via the pathway. As well as postborder surveillance activities and incursion responses, the phytosanitary measures referred to include those set out in the standard "Importation and clearance of fresh fruit and vegetables into New Zealand" (MAF 2008). Nevertheless, to determine more accurately the value of this novel analytical approach, similar analyses of other import pathways could be usefully conducted. Such analyses may assist in providing an indication of the relative risk of establishment of new organisms via different pathways. In addition, the accuracy of the approach could be improved through more detailed examination of the new-to-New Zealand records to separate out records of exotic organisms that have established in New Zealand (albeit for a short time only on occasions) from those that constitute organisms that are believed to be part of New Zealand's previously undescribed or unrecognised native flora and fauna.

\section{ACKNOWLEDGEMENTS}

We wish to acknowledge the assistance of MAF Biosecurity New Zealand's IDC staff, in particular Thérèse Oliver, in obtaining access to Excel files of extracted records from the PPIN and STARS Databases. Without the diagnostic efforts of IDC's Plant Health and Environment Laboratory staff, there would be no identification records to analyse.

\section{REFERENCES}

FAO 1998. International Standards for Phytosanitary Measures No. 8: Determination of Pest Status in an Area. FAO, Rome, Italy. 18 p.

FAO 2007. International Standards for Phytosanitary Measures No. 5: Glossary of Phytosanitary Terms. FAO, Rome, Italy. 112 p.

Frampton ER 2004. Fresh Produce Import Pathway Analysis Using Border Interception and New-to-New Zealand Records. Report prepared for New Zealand Fresh Produce Importers Association Inc. New Zealand Fresh Produce Importers Association, Wellington, New Zealand. 13 p.

Ministry of Agriculture and Forestry 2002. Media Release: Species of crazy ant found at Auckland port. www.maf.govt.nz/mafnet/press/190402crazyants.htm (accessed 13 February 2009).

Ministry of Agriculture and Forestry 2003a. Sea Container Review. MAF Discussion Paper No: 35. Ministry of Agriculture and Forestry, Wellington, New Zealand. $112 \mathrm{p}$.

Ministry of Agriculture and Forestry 2003b. Pest Risk Analysis: Ants on Sawn Timber Imported from the South Pacific Region. Ministry of Agriculture and Forestry, Wellington, New Zealand. 37 p.

Ministry of Agriculture and Forestry Biosecurity New Zealand 2007. Red imported fire ant response gathers speed. Biosecurity 74: 12.

Ministry of Agriculture and Forestry 2008. MAF Biosecurity New Zealand Standard 152.02 Importation and clearance of fresh fruit and vegetables into New Zealand. Ministry of Agriculture and Forestry, Wellington, New Zealand. 13 November 2008. 400 p.

Ministry of Agriculture and Forestry Biosecurity New Zealand 2008. Red Imported Fire Ant. www.biosecurity.govt.nz/pests/red-imported-fire-ant (accessed 13 February 2009).

Worner SP, Gevrey M 2006. Modelling global insect pest species assemblages to determine risk of invasion. Journal of Applied Ecology 43: 858-867. 